\title{
Preparation of goat and rabbit anti-camel immunoglobulin G whole molecule labeled with horseradish peroxidase
}

\author{
Eman Hussein Abdel-Rahman'1, Jakeen Kamal El-Jakee², Mahmoud Essam Hatem²,
} Nagwa Sayed Ata $^{3}$ and Ehab Ali Fouad ${ }^{3}$

1. Department of Parasitology and Animal Diseases, National Research Centre, Egypt; 2. Department of Microbiology, Faculty of Veterinary Medicine, Cairo University, Egypt; 3. Department of Microbiology and Immunology, National Research Centre, Egypt.

Corresponding author: Ehab Ali Fouad, e-mail: ehabfoaud@gmail.com,

Co-authors: EHA: emanhussein1@hotmail.com, JKE: jeljakee@yahoo.com, MEH: mehatem@yahoo.com, NSA: profnagwaata@gmail.com

Received: 26-10-2016, Accepted: 21-12-2016, Published online: 23-01-2017

doi: 10.14202/vetworld.2017.92-100 How to cite this article: Abdel-Rahman EH, El-Jakee JK, Hatem ME, Ata NS, Fouad EA (2017) Preparation of goat and rabbit anti-camel immunoglobulin $\mathrm{G}$ whole molecule labeled with horseradish peroxidase, Veterinary World, 10(1): 92-100.

\begin{abstract}
Aim: As the labeled anti-camel immunoglobulins (Igs) with enzymes for enzyme-linked immunosorbent assay (ELISA) are unavailable in the Egyptian market, the present investigation was directed for developing local labeled anti-camel IgG with horseradish peroxidase (HRP) to save hard curacy.

Materials and Methods: For purification of camel IgG whole molecule, camel sera was preliminary precipitated with $50 \%$ saturated ammonium sulfate and dialyzed against $15 \mathrm{mM}$ phosphate-buffered saline $\mathrm{pH} 7.2$ then concentrated. This preparation was further purified by protein A sepharose affinity column chromatography. The purity of the eluted camel IgG was tested by sodium dodecyl sulfate polyacrylamide gel electrophoresi. Anti-camel IgG was prepared by immunization of goats and rabbits separately, with purified camel IgG. The anti-camel IgG was purified by protein A sepharose affinity column chromatography. Whole molecule anti-camel IgG was conjugated with HRP using glutraldehyde based assay. Sensitivity and specificity of prepared conjugated secondary antibodies were detected using positive and negative camel serum samples reacted with different antigens in ELISA, respectively. The potency of prepared conjugated antibodies was evaluated compared with protein A HRP. The stability of the conjugate at $-20^{\circ} \mathrm{C}$ during 1 year was assessed by ELISA.
\end{abstract}

Results: The electrophoretic profile of camel IgG showed four bands of molecular weight 63, 52, 40 and $33 \mathrm{kDa}$. The recorded sensitivity and specificity of the product are $100 \%$. Its potency is also $100 \%$ compared to $58-75 \%$ of commercial protein A HRP. The conjugates are stable for 1 year at $-20^{\circ} \mathrm{C}$ as proved by ELISA.

Conclusion: Collectively, this study introduces goat and rabbit anti-camel IgG whole molecules with simple, inexpensive method, with $100 \%$ sensitivity, $100 \%$ specificity and stability up to 1 year at $-20^{\circ} \mathrm{C}$. The important facet of the current study is saving hard curacy. Future investigations are necessary for preparation of $\operatorname{IgG}$ subclasses.

Keywords: anti-camel immunoglobulin G, Camelus dromedarius, conjugation, horseradish peroxidase, purification.

\section{Introduction}

The camel occupies a unique position among animals which man has failed to exploit adequately and undoubtedly have unexplored and unrealized potential. From a global perspective, little interests are directed to the economic significance of camel production in comparison with that of other domestic animals. However, camels breeding could be participated efficiently in providing Egyptian's needs of animal protein and its by-products. The main breed is the dromedary of the Nile Delta of Egypt [1]. Improvement of camel production depends on efficient management and diseases control which in turn

Copyright: Abdel-Rahman, et al. Open Access. This article is distributed under the terms of the Creative Commons Attribution 4.0 International License (http://creativecommons.org/licenses/ by/4.0/), which permits unrestricted use, distribution, and reproduction in any medium, provided you give appropriate credit to the original author(s) and the source, provide a link to the Creative Commons license, and indicate if changes were made. The Creative Commons Public Domain Dedication waiver (http:// creativecommons.org/publicdomain/zero/1.0/) applies to the data made available in this article, unless otherwise stated. through understanding of the functioning of its various biological systems, such as the immune system [2]. Concerning camel disease, camels were formerly considered resistant to most of the diseases commonly affecting livestock, but as more research was conducted; camels were found to be susceptible to a large number of pathogenic agents [3].

The availability of proper serodiagnostic aids help in diagnosing a wide range of infectious diseases infects camels [4]. The different serologic tests that were used to diagnose viral, bacterial, and parasitic infections depend on antigen-antibody reactions such as enzyme-linked immunosorbent assay (ELISA) [5,6]. This test needs enzymes conjugated secondary antibodies that are lacked in the Egyptian market and need to be imported with hard curacy.

Hence, the ultimate aim of this study is participating in solving the problem of camel diagnostic reagents lack through introduce one-way to monitor the camel immune responses to different pathogens by developing conjugated secondary anti-camel IgG with 
horseradish peroxidase (HRP). This participation will facilitate accurate diagnosis and control of infectious diseases, which could affect camel welfare and productivity and save hard curacy.

\section{Materials and Methods}

\section{Ethical approval}

Experiments were performed according to the Guide for the care and use of Laboratory animals and Ethical Approval of Animal Rights according to Committee, National Research Centre, Egypt.

\section{Materials}

Protein A sepharose gel has a high binding capacity toward camel immunoglobulin $\mathrm{G}$ ( $\operatorname{IgG}$ ). Ammonium sulfate $\left(\mathrm{NH}_{4}\right)_{2} \mathrm{SO}_{4}$, monobasic sodium phosphate $\left(\mathrm{NaH}_{2} \mathrm{PO}_{4}\right)$, dibasic sodium phosphate $\left(\mathrm{Na}_{2} \mathrm{HPO}_{4}\right)$, orthophenylenediamine, HRP, bovine serum albumin, and protein A conjugate peroxidase were purchased from Sigma. Sera from camels, immunized goats and rabbits were used as the source of polyclonal camel IgG and anti-camel IgG (Bacterial and parasitic antigens were donated by Prof. Dr. Eman H. Abdel-Rahman).

\section{Methods}

Precipitation of Igs with ammonium sulfate solution

About 50\% saturated ammonium sulfate solution (SAS) was used to precipitate Igs. Ammonium sulfate was removed by dialysis against $15 \mathrm{mM}$ phosphate-buffered saline (PBS) for 3 days at $4^{\circ} \mathrm{C}$. The Igs were concentrated by polyethylene glycol or lyophilization according to Abd El Hafez et al. [7].

\section{Purification of IgGs by protein A affinity} chromatography

Protein A sepharose gel was used to purify $\operatorname{IgG}$ using eluting buffer $0.1 \mathrm{M}$ glycine. The separation method was according to Abd El Hafez et al. [7].

\section{Estimation of protein contents of Igs}

The assay was performed according to the method of Lowry et al. [8].

Electrophoresis of camel IgG in sodium dodecyl sulfate polyacrylamide gel electrophoresi (SDS-PAGE)

SDS-PAGE was performed in $10 \%$ polyacrylamide gels according to Laemmli [9]. Camel IgG was mixed with sample buffer containing 2-mercaptoethanol before loading to the gel. After separation, slab gel was stained with Coomassie Brilliant Blue dye. Relative molecular weights of bands were calculated using Protein marker supplied by Sigma-Aldrich. Molecular weights were determined using Bio Rad Gel Doc XR+ Apparatus.

\section{Preparation of anti-camel IgG in goats and rabbits}

Animals immunization was performed according to Muro et al. [10]. The camel IgG was used in concentration of $40 \mu \mathrm{g} / \mathrm{kg}$ body weight of animal and was thoroughly mixed with an equal volume of complete Freund's adjuvant (Difico, USA) and injected subcutaneously. 2 weeks later, first booster dose was given by the same way but with incomplete Freund's adjuvant. The second and third booster doses injected after 21 and 28 days, respectively, without adjuvant. ELISA adopted to evaluate anti-camel IgG production in both goats and rabbits. Antigen concentration, antibody dilution, and anti-species secondary conjugated antibody were determined with checkerboard titration and the assay performed according to Paul and Akira [11].

\section{Labeling of rabbit and goat IgGs with HRP}

About $10 \mathrm{mg}$ of HRP mixed with $5 \mathrm{mg}$ of $\mathrm{IgG}$ in $1 \mathrm{ml}$ total volume of $100 \mathrm{mM}$ phosphate buffer (pH 6.8). The mixture was dialyzed over night at $4^{\circ} \mathrm{C}$ against $100 \mathrm{mM}$ phosphate buffer ( $\mathrm{pH}$ 6.8). $50 \mu 1$ of the diluted glutaraldehyde added to the dialyzed mixture with gentle stirring at room temperature for $3 \mathrm{~h}$. $2 \mathrm{M}$ glycine solution added to obtain a $0.1 \mathrm{M}$ final concentration. The mixture was left at room temperature for $2 \mathrm{~h}$ and then dialyzed over night at $4^{\circ} \mathrm{C}$ against $100 \mathrm{mM}$ PBS. It centrifuged for $30 \mathrm{~min}$ at $10,000 \times g$ at $4^{\circ} \mathrm{C}$. The supernatant transferred in a suitable tube and one volume of distilled glycerol added. The conjugate stored at $-20^{\circ} \mathrm{C}$. The procedures performed according to the method of Avrameas [12].

Assessment of prepared conjugates potency compared with commercial protein A conjugate

ELISA used to assess the development of anticamel IgG in goats and rabbits and to determine the optimum dilutions of prepared conjugates, antigens, and sera concentrations. It was also used to evaluate the potency of prepared conjugates compared with protein A peroxidase and its stability. The assay performed according to Paul and Akira [11].

\section{Results}

Protein content of purified camels, goats and rabbits IgG are shown in Table 1

\section{SDS-PAGE profile of camel IgG}

The electrophoretic profile of camel IgG showed four bands of molecular weight $63,52,40$ and $33 \mathrm{kDa}$ (Figure-1).

\section{Development of anti-camel IgG in goats and rabbits}

As proved by ELISA, the appropriate camel IgG concentration is $20 \mu \mathrm{g} / \mathrm{ml}$, goat and rabbit antibody dilution is $1: 100$ and anti-species secondary conjugated antibody is 1:1000 based on checkerboard titration. Time based goats and rabbits antibody response to camel IgG as shown in Figures-2 and 3.

Table-1: Protein content of purified camels, goats, and rabbits IgG.

\begin{tabular}{|c|c|c|}
\hline Animal & $\begin{array}{l}\text { Protein content of } \\
\text { Igs } \mathrm{mg} / \mathrm{ml}\end{array}$ & $\begin{array}{l}\text { Protein content of } \\
\text { IgG } \mathrm{mg} / \mathrm{ml}\end{array}$ \\
\hline Camel & 3.5 & 2.3 \\
\hline Goat & 2.3 & 1.96 \\
\hline Rabbit & 2.7 & 2.1 \\
\hline
\end{tabular}

IgG: Immunoglobulin G 


\section{Potency of prepared goat and rabbit anti-camel HRP in ELISA}

The optical density (OD) values recorded due to reaction of diseased camel serum samples with different antigens of Echinococcus granulosus; wall, protoscolex and fluid antigens as well as bacterial antigens prepared from Corynebacterium pseudotuberculosis, Staphylococcus aureus, and Escherichia coli using prepared conjugates in ELISA proved validity of both conjugates as shown in Figures-4, 5, 6 and 7.

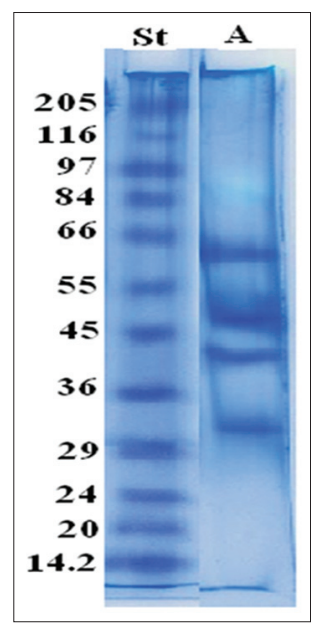

Figure-1: Sodium dodecyl sulfate polyacrylamide gel electrophoresi profile of camel immunoglobulin G. Lane St: Molecular weight marker, Lane A: Camel immunoglobulin G.

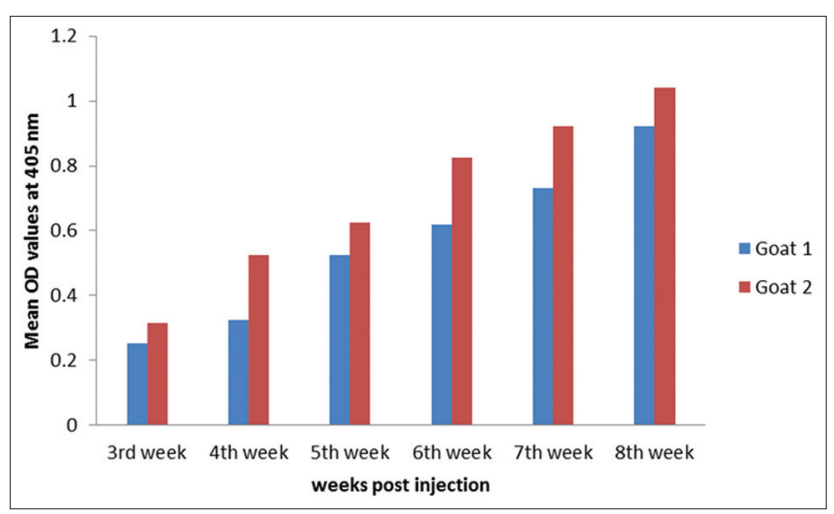

Figure-2: Time based goats antibody response to camel immunoglobulin $G$ measured by enzyme-linked immunosorbent assay.

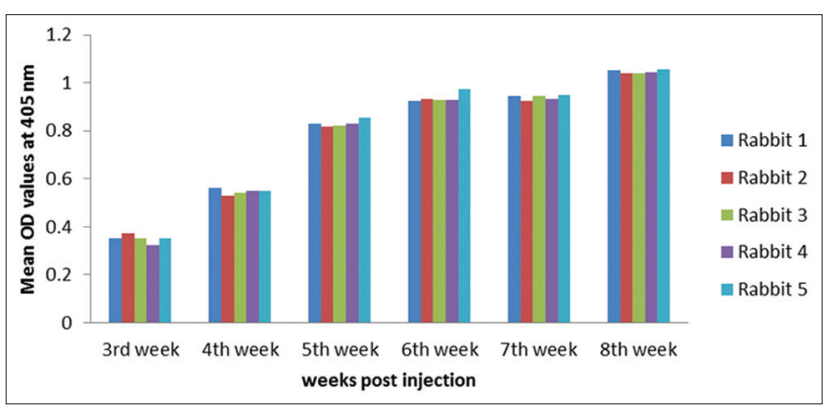

Figure-3: Time based rabbits antibody response to camel immunoglobulin $\mathrm{G}$ measured by enzyme-linked immunosorbent assay.

\section{Conjugates sensitivity}

The sensitivity of prepared conjugates is $100 \%$ (Figures-8, 9 and 10).

\section{Conjugates specificity}

The specificity of prepared conjugates is $100 \%$ compared to $58-75 \%$ of commercial protein A HRP that are shown in Table 2 and Figures-11, 12 and 13).

\section{Conjugates stability}

The conjugates are stable for 1 year at $-20^{\circ} \mathrm{C}$ that are shown in Table 3 and (Figures-14 and 15).

\section{Discussion}

This study directed for development of polyvalent anti-camel IgG labeled with HRP. The procedure followed in this study was precipitation of camel Igs by SAS. The selection of this method was based on the previous results demonstrated that ammonium sulfate gives the best combination of high purity and yield, also ammonium sulfate is inexpensive and used for purification of Igs in large scale production $[13,14]$. The best condition for fractionation of $\mathrm{IgG}$ from the other proteins in camel serum was use of 55\% ammonium sulfate which is comparable to the condition used in the current study proved by Khamehchian et al. [15].

The purification of IgG using protein A Sepharose affinity chromatography was used in the present study, to isolate IgG from camels, goats and rabbits serum samples. Adoption of this method is easy and gives large amount of highly purified yield of IgG [16]. This approach was supported with Jungbauer et al. [17] who compared affinity chromatography with protein A sepharose and protein G Sepharose methods for purification. Protein A sepharose was shown to be a powerful method for the isolation and purification of IgG antibodies from camels serum. While affinity chromatography with protein $\mathrm{G}$ sepharose bonded weakly to camel's IgG and the performed experiment showed high losses of IgG which could be unacceptable.

Moreover, purification of serum IgG by affinity chromatography is more efficient than with diethylaminoethy-cellulose column chromatography that is more expensive. The affinity chromatography is simple, one step and highly efficient method for IgG purification compared with ion exchange chromatography recorded by Mariam et al. [14] and El-Hewairy et al. [18]. Hence, the affinity chromatography method was used as method of choice in the present work.

If a highly purified product is required, an assay for assessing the degree of protein purity is essential. The method of choice for determining purity in the current study is SDS-PAGE. Molecular weights of camel IgG four bands were 63, 52, 40 and $33 \mathrm{kDa}$. Previously, characterization of $\mathrm{IgG}$ was done using $12 \%$ SDS-PAGE under reducing conditions. Protein bands were visualized after staining with Coomassie Brilliant Blue, showing four bands; two bands at 


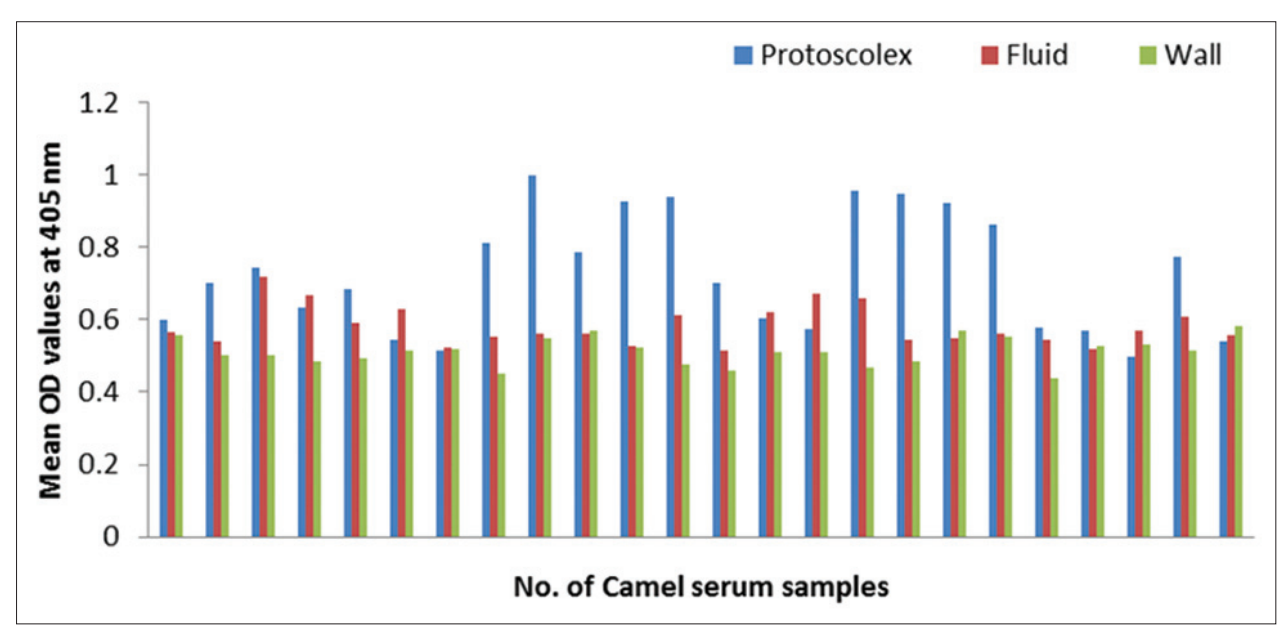

Figure-4: Comparative evaluation of goat anti-camel horseradish peroxidase potentials in detection of immunoglobulin G in camel serum samples react with different Echinococcus granulosus antigens.

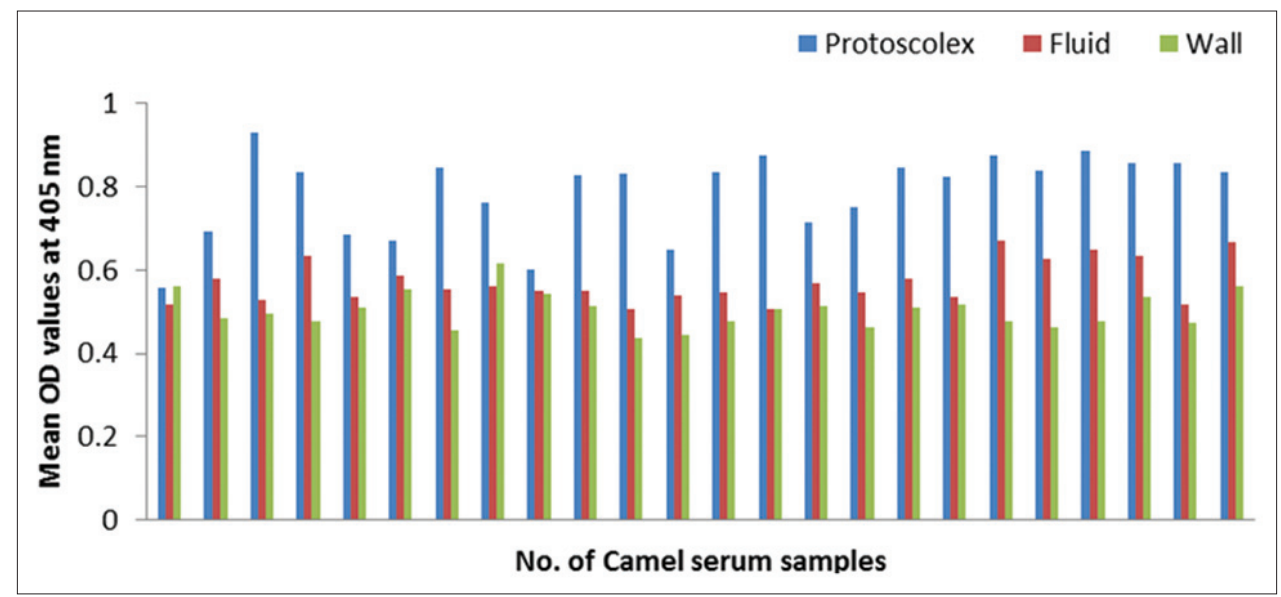

Figure-5: Comparative evaluation of rabbit anti-camel horseradish peroxidase potentials in detection of immunoglobulin $\mathrm{G}$ in camel serum samples react with different Echinococcus granulosus antigens.

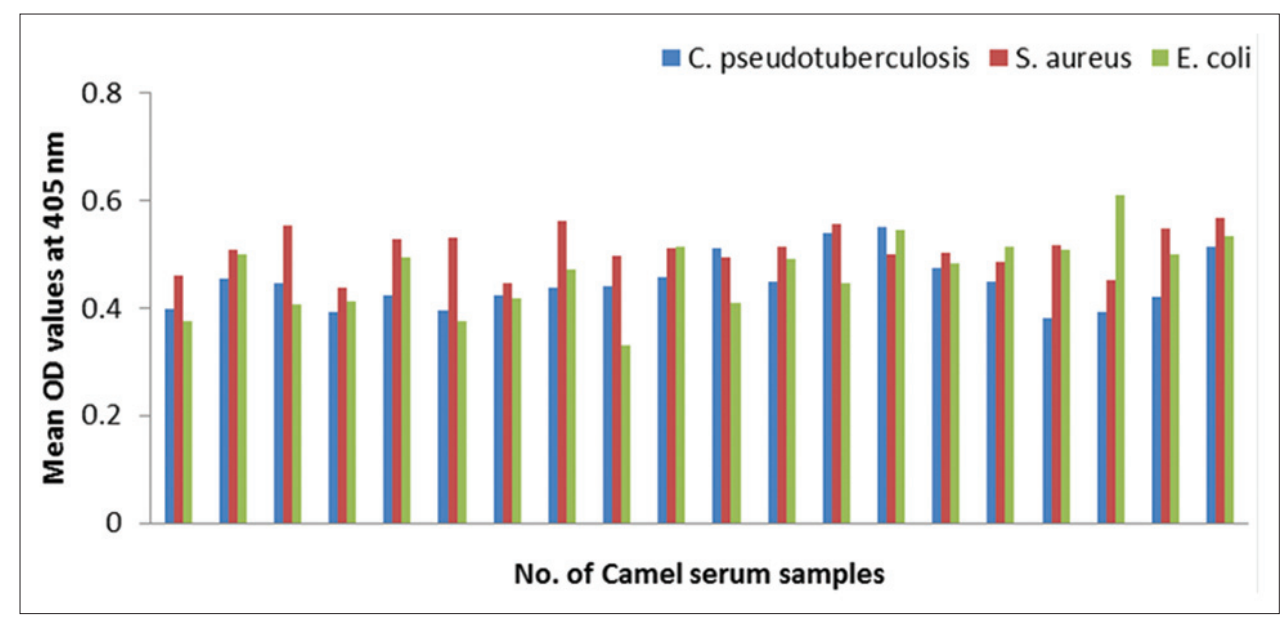

Figure-6: Comparative evaluation of goat anti-camel horseradish peroxidase potentials in detection of immunoglobulin $\mathrm{G}$ in camel serum samples react with different bacterial antigens.

50 and $30 \mathrm{kDa}$ in case of $\mathrm{IgG}_{1}$ while $\mathrm{IgG}_{2}$ and $\mathrm{IgG}_{3}$ produce only one band at 46 and $43 \mathrm{kDa}$, respectively $[16,19,20]$. Under reducing conditions, $\operatorname{IgG}_{1}$ was resolved into light chain $(22.7 \mathrm{kDa})$ and one heavy chain $(49.4 \mathrm{kDa})$. The $\mathrm{IgG}_{3}$ preparation was reduced to one dominant heavy-chain species of $42.1 \mathrm{kDa}$. The $\mathrm{IgG}_{2}$ preparation was reduced to one dominant heavy-chain species of $40.9 \mathrm{kDa}$ [21]. While, using $12 \%$ SDS-PAGE to study the camel IgG that appeared as three bands of 52, 46 and $30 \mathrm{kDa}$ [7]. The camel IgG as 2 bands with molecular masses of 150 and $75 \mathrm{kDa}$ presented by Khamehchian et al. [15]. The difference in number of bands between the current results and previous ones probably attributed to differences in 


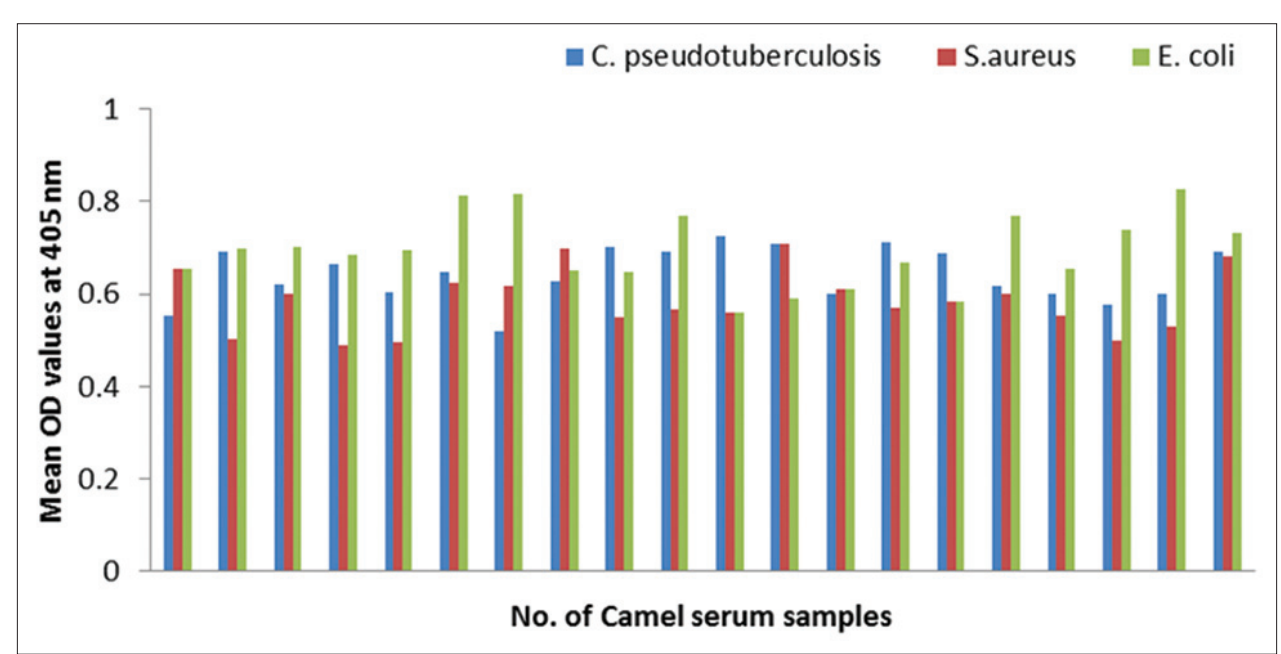

Figure-7: Comparative evaluation of rabbit anti-camel horseradish peroxidase potentials in detection of immunoglobulin $\mathrm{G}$ in camel serum samples react with different bacterial antigens.

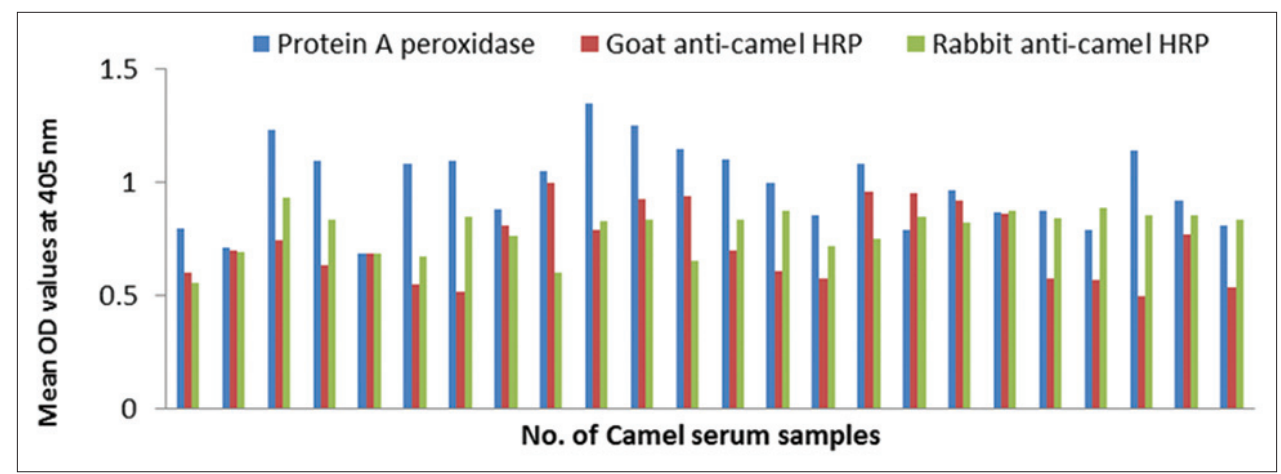

Figure-8: Comparative sensitivities of protein A peroxidase, goat and rabbit anti-camel horseradish peroxidase in detection of immunoglobulin $\mathrm{G}$ in positive camel serum samples specific to Echinococcus granulosus protoscolex antigen.

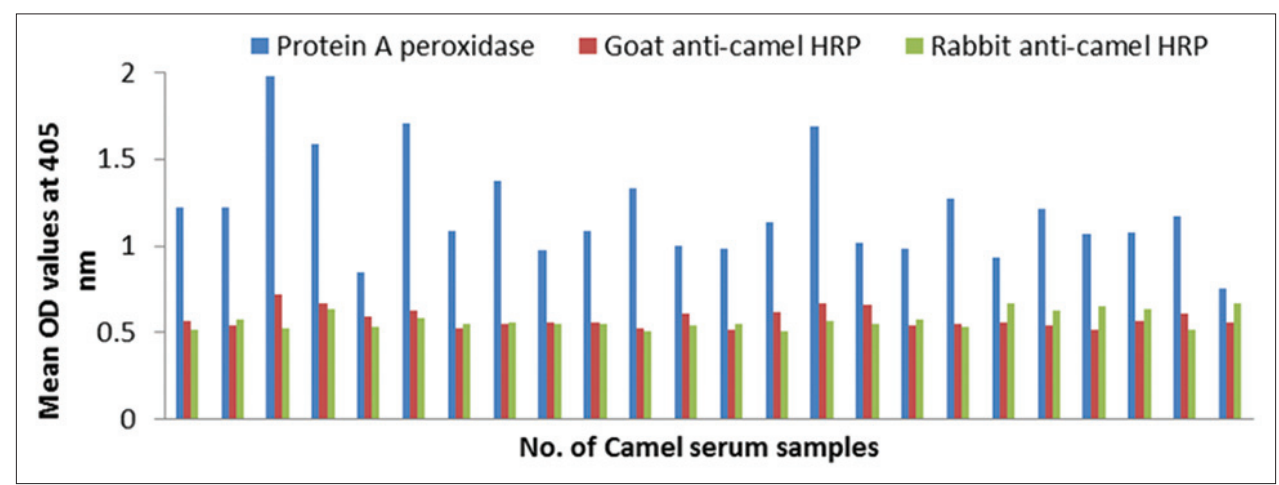

Figure-9: Sensitivity evaluation of goat and rabbit anti-camel horseradish peroxidase compared with protein A peroxidase in detection of immunoglobulin $\mathrm{G}$ in positive camel serum samples reacted with Echinococcus granulosus fluid antigen.

sample preparation, which includes breakage of disulfide bonds of the molecule using $\beta$ mercaptoethanol, and consequently, determine the number of bands in addition to different used stains, silver or Coomassie to visualize separated bands.

After purification of camel IgG, goats and rabbits separately inoculated to produce anti-camel IgG. Goats and rabbits are widely used for production of specific antibodies [22]. In this study, goats and rabbits received at least four subcutaneous injections each of $40 \mu \mathrm{g} / \mathrm{kg}$ body weight of animal using complete and incomplete Freund's adjuvant (Difico, USA).
This approach was previously adopted by Toaleb et al. [23], Abdel-Rahman et al. [24] who administrated $40 \mu \mathrm{g} / \mathrm{kg}$ of rabbit using Freund's complete and incomplete adjuvant and injected subcutaneously. Different protocols previously adopted for development of anti-camel IgG. The previous studies $[22,25]$ injected higher concentrations of camel IgG than that in the current study and used intramuscular route. Subcutaneous route is better than intramuscular one as no ulcerative lesions appear and is less painful [16]. In this study, the success of developing anti-camel $\mathrm{IgG}$ in both goats and rabbits monitored by indirect 
Table-2: Comparitive specificities of protein A peroxidase, goat and rabbit anti-camel HRP using negative camel serum samples and E. granulosus antigens.

\begin{tabular}{|c|c|c|c|c|c|c|c|c|c|}
\hline \multirow{3}{*}{$\begin{array}{l}\text { Number } \\
\text { of } \\
\text { camel } \\
\text { samples }\end{array}$} & \multicolumn{9}{|c|}{ OD values of-ve camel serum samples and $E$. granulosus antigens } \\
\hline & \multicolumn{3}{|c|}{ Protoscolex antigen } & \multicolumn{3}{|c|}{ Fluid antigen } & \multicolumn{3}{|c|}{ Wall antigen } \\
\hline & $\begin{array}{c}\text { Protein A } \\
\text { peroxidase }\end{array}$ & $\begin{array}{c}\text { Goat anti } \\
\text {-camel } \\
\text { HRP }\end{array}$ & $\begin{array}{c}\text { Rabbit } \\
\text { anti-camel } \\
\text { HRP }\end{array}$ & $\begin{array}{c}\text { Protein A } \\
\text { peroxidase }\end{array}$ & $\begin{array}{l}\text { Goat anti } \\
\text {-camel } \\
\text { HRP }\end{array}$ & $\begin{array}{c}\text { Rabbit } \\
\text { anti-camel } \\
\text { HRP }\end{array}$ & $\begin{array}{c}\text { Protein A } \\
\text { peroxidase }\end{array}$ & $\begin{array}{c}\text { Goat } \\
\text { anti-camel } \\
\text { HRP }\end{array}$ & $\begin{array}{c}\text { Rabbit } \\
\text { anti-camel } \\
\text { HRP }\end{array}$ \\
\hline 1 & $0.925 *$ & 0.201 & 0.165 & $0.921 *$ & 0.301 & 0.210 & $0.905 *$ & 0.198 & 0.066 \\
\hline 2 & 0.399 & 0.199 & 0.158 & 0.319 & 0.210 & 0.185 & 0.362 & 0.165 & 0.122 \\
\hline 3 & 0.352 & 0.175 & 0.140 & $0.978 *$ & 0.221 & 0.194 & $0.921 *$ & 0.201 & 0.101 \\
\hline 4 & 0.311 & 0.210 & 0.197 & $0.841 *$ & 0.196 & 0.098 & 0.354 & 0.175 & 0.135 \\
\hline 5 & 0.202 & 0.166 & 0.099 & 0.351 & 0.165 & 0.124 & 0.324 & 0.177 & 0.157 \\
\hline 6 & 0.352 & 0.325 & 0.249 & $0.886 *$ & 0.214 & 0.123 & 0.275 & 0.169 & 0.096 \\
\hline 7 & 0.242 & 0.215 & 0.199 & $0.984 *$ & 0.201 & 0.214 & 0.356 & 0.197 & 0.145 \\
\hline 8 & 0.300 & 0.199 & 0.201 & 0.378 & 0.211 & 0.187 & 0.365 & 0.165 & 0.111 \\
\hline 9 & $0.798 *$ & 0.231 & 0.165 & 0.279 & 0.189 & 0.165 & $0.977 *$ & 0.175 & 0.143 \\
\hline 10 & 0.341 & 0.258 & 0.147 & 0.281 & 0.177 & 0.203 & 0.265 & 0.098 & 0.109 \\
\hline 11 & 0.309 & 0.236 & 0.098 & 0.234 & 0.206 & 0.144 & 0.321 & 0.210 & 0.097 \\
\hline 12 & $0.932 *$ & 0.245 & 0.142 & 0.198 & 0.198 & 0.102 & $0.898^{*}$ & 0.187 & 0.169 \\
\hline
\end{tabular}

Standard deviation ranged (0.007-0.01), *Positive. HRP=Horseradish peroxidase, OD=Optical density,

E. granulosus $=$ Echinococcus granulosus

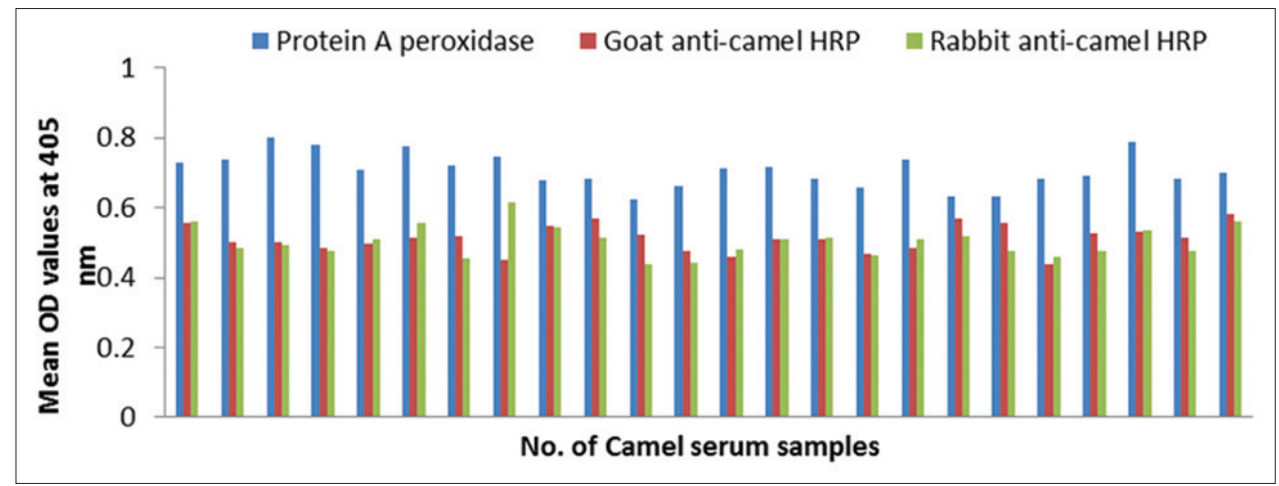

Figure-10: Sensitivity evaluation of goat and rabbit anti-camel horseradish peroxidase compared to protein $\mathrm{A}$ peroxidase in detection of immunoglobulin $\mathrm{G}$ in positive camel serum samples reacted with Echinococcus granulosus wall antigen.

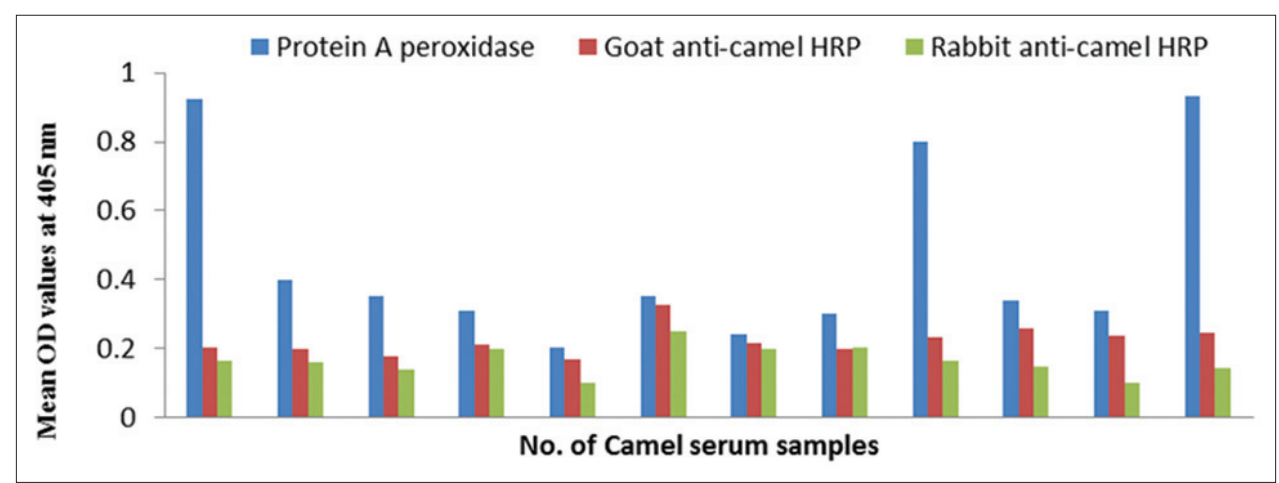

Figure-11: Specificity evaluation of goat and rabbit anti-camel horseradish peroxidase compared with protein A peroxidase using negative camel serum samples and Echinococcus granulosus protoscolex antigen.

ELISA in which commercial anti-goat and anti-rabbit HRP were used. Previously, agar gel diffusion test was the test of choice $[7,18]$. This test checked if the antibodies were developed or not and did not give any indication about the titer of developed antibodies. In contrary, ELISA not only proved the production of antibodies but also facilitated the follow-up of the titer during different intervals post injection to determine the time of blood collection accurately. The method, which was selected in the current study for preparation of goats and rabbits anti-camel antibodies, gave high $\operatorname{IgG}$ response to lower concentration of $\operatorname{IgG}$ than other techniques.

In the present work, the conjugation process was based on using glutaraldehyde as the coupling agent that resulted in conjugates capable of 


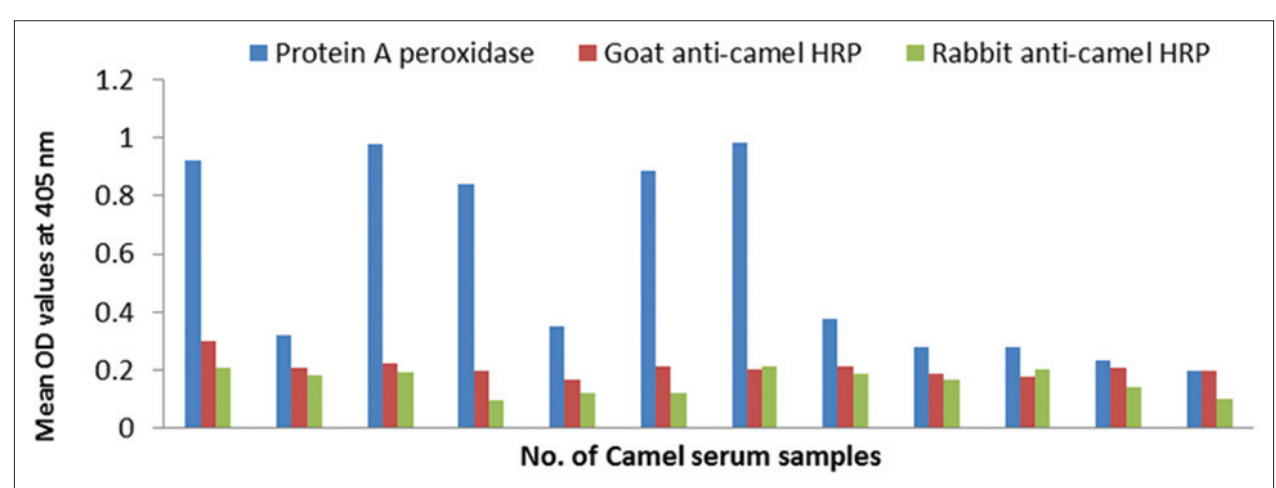

Figure-12: Specificity evaluation of goat and rabbit anti-camel horseradish peroxidase compared with protein A peroxidase using negative camel serum samples and Echinococcus granulosus fluid antigen.

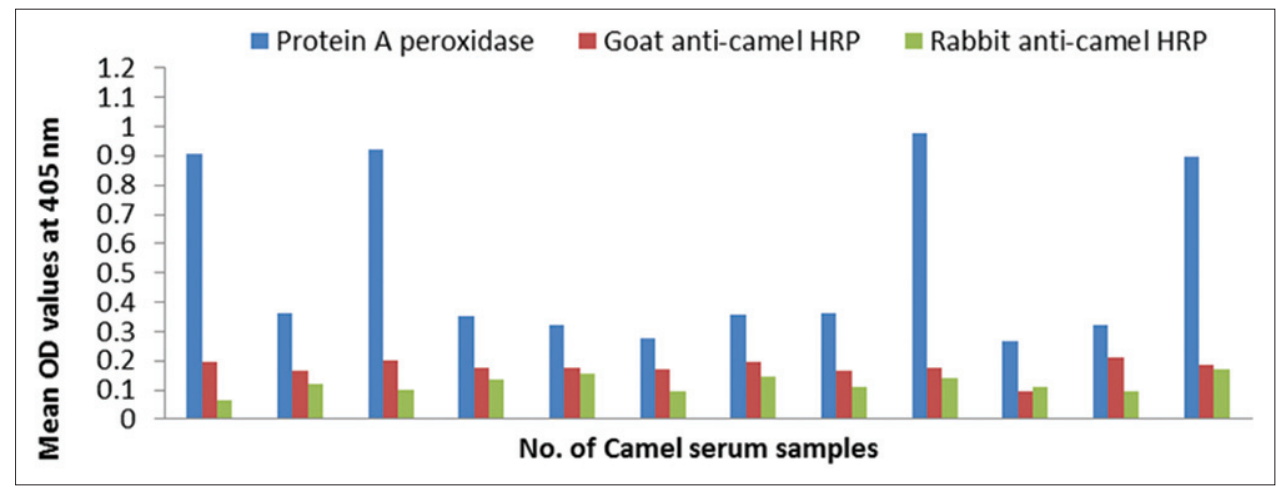

Figure-13: Specificity evaluation of goat and rabbit anti-camel horseradish peroxidase compared with protein A peroxidase using negative camel serum samples and Echinococcus granulosus wall antigen.

Table-3: Stability of stored conjugates at $-20^{\circ} \mathrm{C}$ for 1 year.

\begin{tabular}{|c|c|c|c|c|c|c|}
\hline \multirow{3}{*}{$\begin{array}{l}\text { Number } \\
\text { of camel } \\
\text { serum } \\
\text { sample }\end{array}$} & \multicolumn{6}{|c|}{ Mean OD values \pm standard deviation } \\
\hline & \multicolumn{3}{|c|}{ Goat anti-camel HRP } & \multicolumn{3}{|c|}{ Rabbit anti-camel HRP } \\
\hline & $\begin{array}{l}\text { Freshly } \\
\text { prepared }\end{array}$ & $\begin{array}{l}\text { Stored for } 6 \\
\text { months at }-20^{\circ} \mathrm{C}\end{array}$ & $\begin{array}{c}\text { Stored for } \\
1 \text { year at }-20^{\circ} \mathrm{C}\end{array}$ & $\begin{array}{l}\text { Freshly } \\
\text { prepared }\end{array}$ & $\begin{array}{l}\text { Stored for } 6 \\
\text { months at }-20^{\circ} \mathrm{C}\end{array}$ & Stored for 1 year at $-20^{\circ} \mathrm{C}$ \\
\hline 1 & 0.600 & 0.578 & 0.550 & 0.557 & 0.540 & 0.514 \\
\hline 2 & 0.701 & 0.695 & 0.655 & 0.693 & 0.600 & 0.554 \\
\hline 3 & 0.742 & 0.741 & 0.761 & 0.932 & 0.845 & 0.822 \\
\hline 4 & 0.635 & 0.629 & 0.614 & 0.836 & 0.777 & 0.725 \\
\hline 5 & 0.684 & 0.677 & 0.666 & 0.686 & 0.632 & 0.610 \\
\hline 6 & 0.546 & 0.546 & 0.532 & 0.672 & 0.620 & 0.554 \\
\hline 7 & 0.514 & 0.509 & 0.500 & 0.847 & 0.742 & 0.721 \\
\hline 8 & 0.811 & 0.805 & 0.785 & 0.763 & 0.604 & 0.598 \\
\hline 9 & 0.997 & 0.990 & 0.888 & 0.600 & 0.521 & 0.500 \\
\hline 10 & 0.788 & 0.772 & 0.750 & 0.829 & 0.711 & 0.644 \\
\hline 11 & 0.925 & 0.914 & 0.899 & 0.832 & 0.765 & 0.689 \\
\hline 12 & 0.940 & 0.934 & 0.900 & 0.650 & 0.612 & 0.565 \\
\hline 13 & 0.701 & 0.695 & 0.650 & 0.834 & 0.735 & 0.699 \\
\hline 14 & 0.605 & 0.600 & 0.555 & 0.875 & 0.714 & 0.654 \\
\hline 15 & 0.575 & 0.555 & 0.489 & 0.716 & 0.612 & 0.588 \\
\hline
\end{tabular}

$\mathrm{HRP}=$ Horseradish peroxidase, $\mathrm{OD}=$ Optical density

detecting antigen-antibody reaction. The selection of this method was based on the previous results demonstrated that glutaraldehyde was the most effective and suitable reagent for producing protein-enzyme complexes which retained a part of their enzymatic and immunological specificity [12]. The conjugation method in which glutaraldehyde is adopted produces mono-functional linkers [26]. In the present work, the conjugation process was applied using HRP as it was inexpensive, easy handling and available in the market without restrictions.

For evaluation of the validity of prepared conjugates, its sensitivity in detection of antigen-antibodies reaction was assessed. All parasitologically or bacteriologically positive camel serum samples were proved to be serologically positive as judged by ELISA in which prepared conjugates were utilized. This means that labeled conjugates could detect positive infection 


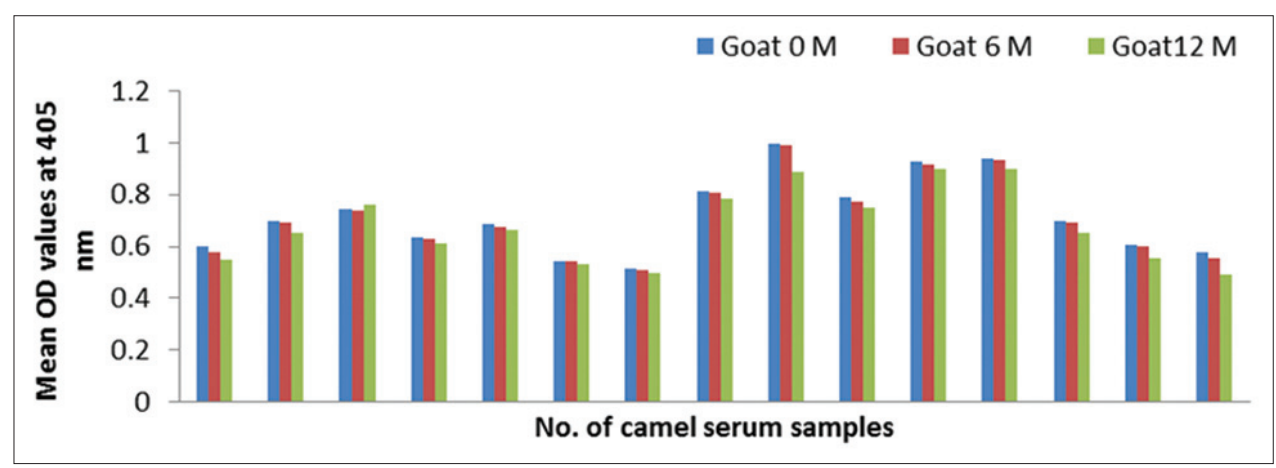

Figure-14: Significant stability of stored goat anti-camel horseradish peroxidase for 1 year at $-20^{\circ} \mathrm{C}$.

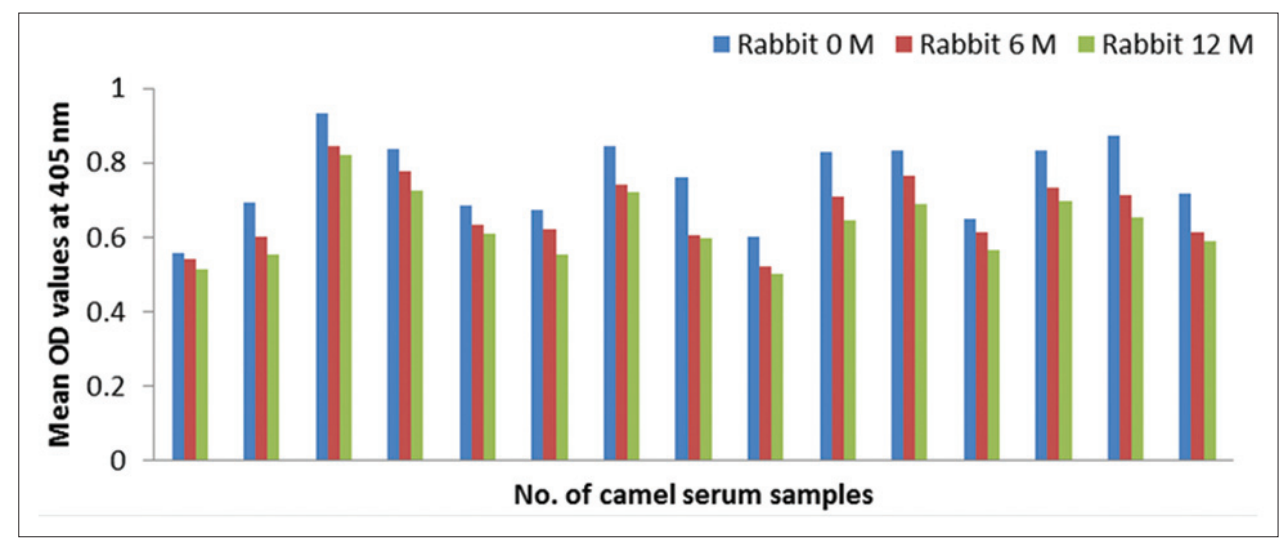

Figure-15: Significant stability of stored rabbit anti-camel horseradish peroxidase for 1 year at $-20^{\circ} \mathrm{C}$.

serologically recording $100 \%$ sensitivity. These results were compared with that obtained using commercial protein A peroxidase as reference. This comparative evaluation confirmed prepared conjugates validity where protein A peroxidase recorded also $100 \%$ sensitivity. This percentage was previously reported by El-Hewairy et al. [18] who prepared goat and rabbit anti-camel IgG alkaline phosphatase and recorded $100 \%$ sensitivity. While, $94.8 \%$ sensitivity of the prepared goat anti-camel IgG conjugate was recorded by El-Hewairy and Syame [27] compared with $72.2 \%$ of protein A alkaline phosphatase. This low sensitivity may be concerned with low titer of antibodies in the misdiagnosed samples or inefficient coupling process between antibody and enzyme but in all cases, it supports the success of the current trial.

In the current study, the specificity of developed conjugates was $100 \%$. Unexpectedly, protein A peroxidase reacted positively with some negative samples recording non-specific reaction ranged from $25 \%$ to $41 \%$. This observation could be attributed to non-specific reaction of protein A with IgGs [28].

Non-significant differences were observed in mean OD values after 1 year of conjugates storage at $-20^{\circ} \mathrm{C}$ as proved by ELISA. In previous study, the activity of stored conjugates decreased with time at $4^{\circ} \mathrm{C}$ and completely lost after 1 year at $-20^{\circ} \mathrm{C}$ [18]. This observation probably reflects the unsuccessful of conjugation process that may result in damage or breakage the bond between primary and secondary antibodies or loss in enzyme activity with its substrate or both due to storage at $4{ }^{\circ} \mathrm{C}$ or $-20^{\circ} \mathrm{C}$.

Collectively, the current product was proved to possess high potentials as compared with protein A peroxidase and showed stable activity for 1 year at $-20^{\circ} \mathrm{C}$. Additional evaluation of conjugates stability needed at $4^{\circ} \mathrm{C}$ and for more than 1 year.

\section{Conclusion}

From the current results, it concluded that new preparations of anti-camel $\mathrm{IgG}$ developed in goats and rabbits. Prepared conjugates characterized by $100 \%$ sensitivity in ELISA using positive camel serum samples. They also showed $100 \%$ specificity compared to $58-75 \%$ of protein A peroxidase using negative samples. The conjugates are stable for 1 year at $-20^{\circ} \mathrm{C}$. Collectively, conjugated anti-camel IgGs developed by easy, simple and inexpensive method and participate in solving the problem of camel diagnostic reagents lack in the Egyptian market in addition to save hard curacy.

\section{Authors' Contributions}

EHA participated in antigens preparations, conjugations and ELISA. She also participated in revising manuscripts. EAF is mainly participating for the practical part and writing the manuscript. NSA revised the results and manuscript. JKE revised the results and manuscript. MEH was sick and died before participating in research. 


\section{Acknowledgments}

The current research is financially supported by National Research Centre, Cairo, Egypt under registration number 12/5/1.

\section{Competing Interests} interests.

The authors declare that they have no competing

\section{References}

1. Nawito, M.F., Shalash, M.R., Hoppe, R. and Rakha, A.M. (1967) Reproduction in female camel. Egypt. Nat. Res. Cent. Bull., 2: 82

2. Azwai, S.M., Carter, S.D. and Woldehiwet, Z. (1996) Immunoglobulins of camel (Camelus dromedarius) colostrum. J. Comp. Pathol., 114: 273-282.

3. Agab, H. (1993) Epidemiology of camel disease in Eastern Sudan, with emphasis on brucellosis. M.V.Sc. Thesis. University of Khartoum. p172-175.

4. Al-Ruwaili, M.A., Khalil, O.M. and Selim, S.A. (2012) Viral and bacterial infections associated with camel (Camelus dromedarius) calf diarrhea in North Province, Saudi Arabia. Saudi J. Biol. Sci., 19(1): 35-41.

5. Mohammed, M.A., Shigidy, M.T. and Al Juboori, A.Y (2013) Sero-prevalence and epidemiology of Brucellosis in camels, sheep and goats in Abu Dhabi Emirate. Int. J. Anim. Vet. Adv., 5(2): 82-86

6. El-Hewairy, H.M., Galal, S.A. and Mousa, W.M. (2014) New approach for diagnosis of Trypanosomes evansi in camel (Camelus dromedaries) by ELISA. Life Sci. J., 11(10): 1258-1263.

7. Abd El Hafez, S.M., Anwar, A.M., Ibrahim, A.M., Mahmoud, M.B. and Hassan, H.M. (2010) Preparation of fluoresce isothiocyanate conjugated IgG (FITC) anti-camel and anti-buffalo. Nat. Sci. J., 8: 342-347.

8. Lowry, O.H., Rosebrough, N.J., Farr, A.L. and Randall, R.J. (1951) Protein measurement with the folin phenol reagent. Biol. Chem. J., 193: 265-275.

9. Laemmli, U.K. (1970) Cleavage of structural protein during the assembly of the head of bacteriophage T4. Nat. J., 227: 680-685.

10. Muro, A., Ramajo, V., Lopez, J., Simon, F. and Hillyer, G.V. (1997) Fasciola hepatica vaccination of rabbits with native and recombinant antigens related to fatty acid binding proteins. Vet. Parasitol. J., 69: 219-229.

11. Paul, K.N. and Akira, K. (1974) Peroxidase-labeled antibody. A new method of conjugation. Histochem. Cytochem. J., 22: 1084-1091.

12. Avrameas, S. (1969) Coupling of enzymes to proteins with glutaraldehyde. Use of the conjugates for the detection of antigens and antibodies. Immunochem. J., 5: 43-52.

13. Roghaye, A., Mahdian, R., Behdani, M., Khanahmad, H., Langari, J., Namvarasl, N., Hassanzadeh-Ghasabeh, R. and Zeinali, S. (2014) Recombinant expression and purification of human placental growth factor 1 and specific camel heavy chain polyclonal antibody preparation. Saudi J. Biol. Sci., 21(1): 35-39.

14. Mariam, S.H.S., Ooi, C.W., Tan, W.S., Janna, O.A., Arbakariya, A. and Tey, B.T. (2015) Purification of rabbit polyclonal immunoglobulin $G$ with ammonium sulphate precipitation and mixed-mode chromatography. Sep. Purif. Technol. J., 144: 133-138.
15. Khamehchian, S., Zolfagharian, H., Dounighi, N. M., Tebianian, M. and Madani, R. (2014) A new approach to prepare Naja Naja oxiana antivenom as passive immunization for therapy. Hum. Vaccin. Immunother. J., 10: 1633-1638.

16. Blanc, M.R., Anouassi, A., Abed, M.A., Canépa, S., Labas, V. and Bruneau, G. (2009) A new method to discriminate immunogen-specific heavy-chain homodimer from heterotetramer immunoglobulin $\mathrm{G}$ directly in immunized dromedary whole plasma proteins: Western ligand blotting. Vet. Immunol. Immunopathol. J., 127: 340-349.

17. Jungbauer, A., Tauer, C., Reiter, M., Purtscher, M., Wenisch, E., Steindi, F., Buchacher, A. and Katinger, H. (1989) Comparison of protein A, protein G and copolymerized hydroxyapatite for the purification of human monoclonal antibodies. Chromatogr. J., 476: 257-268.

18. El-Hewairy, H.M., Moussa, W.M., El-Abeidy, A.A. and Seim, S.A. (2004) Preparation of anti-camel immunoglobulin-G conjugated with fluorescin isothiocyanate and alkaline phosphatase. $1^{\text {st }}$ Anniversary Conference, FVM., Moshtohor. p59-66.

19. Mohammadian, T., Doosti, M., Paknejad, M., Siavoshi, F. and Massarrat, S. (2010) Preparative SDS-PAGE electroelution for rapid purification of alkyl hydroperoxide reductase from Helicobacter pylori. Iran. Public Health J., 39: 85-91.

20. Shaker, G.H. and Melake, N.A. (2012) Use of the single cell gel electrophoresis (comet assay) for comparing apoptotic effect of conventional antibodies versus nanobodies. Saudi Pharm. J., 20: 221-227.

21. Daley, L.P., Gagliardo, L.F., Duffy, M.S., Smith, M.C. and Appleton, J.A. (2005) Application of monoclonal antibodies in functional and comparative investigations of heavy-chain immunoglobulins in new world camelids. Clin. Diagn. Lab. Immunol. J., 12: 380-386.

22. Kataria, A.K. and Sharma, K.N. (2000) Chromatographic purification of serum and colostral immunoglobulins of camel (Camelus dromedarius). Camel Pract. Res. J., 7: 91-95.

23. Toaleb, N.I., Shaapan, R.M., Hassan, S.E. and El Moghazy, F.M. (2013) High diagnostic efficiency of affinity isolated fraction in camel and cattle toxoplasmosis. World Med. Sci. J., 8: 61-66.

24. Abdel-Rahman, E.H., Bashtar, A.M., Hassanain, M.A., Hassanain, N.A. and Toaleb, N.I. (2014) Evaluation of a vaccine candidate isolated from fasciola gigantica excretory-secretory products in rabbits. Glob. Vet., 13(5): 720-727.

25. Agindotan, B.O., Thottappilly, G., Uwaifo, A. and Winter, S. (2003) Production of monoclonal and polyclonal antibodies against a Nigerian isolate of banana streak virus. Afr. Biotechnol. J., 2: 171-178.

26. Imigawa, M., Yoshitake, S., Hamaguchi, Y., Ishikawa, E., Niitsu, Y., Urushizaki, I., Kanazawa, R., Tachibana, S., Nakazwa, N. and Ogawa, H.H. (1982) Characteristics and evaluation of horseradish peroxidase conjugates prepaed by using a maleimide compound, gluteraldehyde and periodate. Immunoassay J., 4: 207-211.

27. El-Hewairy, H.M. and Syame, S.M. (2008) Preparation of polyvalent anti-camel immuonoglobulins labeled with alkaline phosphates. Egypt. Comp. Pathol. Clin. Pathol. J., 21: 93-101.

28. Rae, P.F., Thrusfield, M.V., Higgins, A., Aitken, C.G.G., Jones, T.W. and Luckins, A.G. (1989) Evaluation of enzyme immunoassay in the diagnosis of camel (Camelus dromedarius) trypanosomiasis: A preliminary investigation. Infect. Sci. J., 102: 297-307. 